\title{
NEW HOST AND LOCALITY RECORDS OF MYXOBOLUS CAUDATUS INFECTING BARBUS SHAPREYI (CYPRINIDAE) FROM EUPHRATES RIVER AT RAMADI CITY, IRAQ: LIGHT AND TRANSMISSION ELECTRON MICROSCOPIC STUDY By
}

\author{
SALAM FLAYYIH ATTALLAH AL-HASHIMI \\ Ministry of Education, Iraq Education of Anbar Governorate, Anbar, Iraq \\ (Correspondence: Salamfys@yahoo.com) \\ Abstract
}

\begin{abstract}
Myxobolus Bütschli, 1882 (Myxozoa, Myxosporea, Bivalvulida, Myxobolidae) is an important parasitic protozoan of freshwater fishes reported from almost the worldwide. The severity of infection may lead to mortality of the host fish. During a parasitological survey on parasites infecting fishes caught from Euphrates River at Ramadi City, Iraq during regular visits between March and September 2016, 8/26 specimens of binni fish, Barbus shapreyi (F: Cyprinidae) were found to be naturally infected with Myxobolus caudatus. The infection was recorded as small whitish plasmodia embedded in the caudal fin of infected host. The number of plasmo-

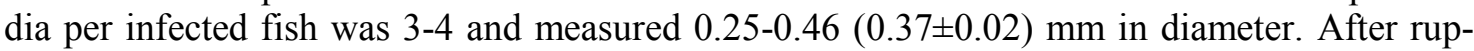

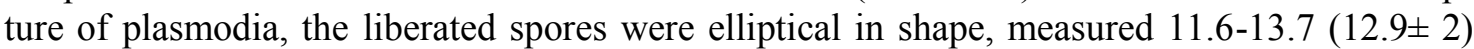
$\mu \mathrm{m}$ in length and 6.4.0-8.3 (7.4 \pm 2$) \mu \mathrm{m}$ in width. The polar capsules were elliptical, equal in

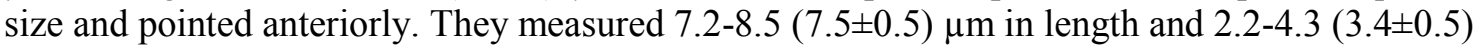
$\mu \mathrm{m}$ in width. Examination of ultrathin sections through the parasite plasmodia by transmission electron microscope showed that the process of capsulogeneis followed the usual pattern of bivalvulid spore development with asynchronous type of polar capsule maturation. Also, the formation of polar filament (6-9 coils) occurred after the fusion of external tubules with capsular primordia. The process of valvogenesis also described when two valvogenic cells met at one pole of the spore with a sutural line in between. By comparison between the isolated spores in the present study and those isolated previously from fish hosts at Iraq water sources, it showed the present parasite to be complete different with new host and locality records in Iraq.

Key words: Myxobolus caudatus, Barbusshapreyi,Euphrates River-Ramadi City-Iraq-Light and transmission electron microscopic study
\end{abstract}

\section{Introduction}

Bivalvulid myxosporeans classified in the genus Myxobolus Bütschli, 1882, are distinctly specious in the systematics of Myxozoa (Lom and Dyková, 2006), about nearly 900 nominal species (Landsberg and Lom, 1991; Eiras et al, 2005, 2014; Abdel-Ghaffar et al, 2017). The diminutive spores are simple in morphology without external projections, ellipsoidal, ovoid or rounded in valvular view and biconvex in sutural view, and contain two polar capsules mostly pyriform, equal or unequal, closely set in the anterior part of the spore on the sutural plane (Lom and Dyková, 2006; Fiala et al, 2015). Despite specific differentiation based solely on the morphology of the bivalvulid spore, i.e., shape and dimensions, being rather difficult, Myxobolus spp. have been demonstrat- ed to show highly narrow host, organ, and tissue specificities (Molnár, 1994, 2002a,b; Cech et al, 2012; Molnár and Eszterbauer, 2015). In other words, the development of plasmodia mostly occurs in a well-defined part of an organ in a certain category of fish, e.g., only in one host species or in closely related fish (Eszterbauer, 2004; Molnár and Eszterbauer, 2015). Over 2,180 species of Myxosporea belonging to approximately 60 genera were described (Eiraset al, 2014). They were reported from different geographical areas, mainly as parasites and pathogens of fish. During the last few years, a great advance was achieved in fish farming in general and fish cages in particular due to the increasing demand on fish protein as well as the increasing investment in fishculture industry in most provinces of Iraq. 
According to the statistics, a total of 441 working fish farms are scattered in Iraq (MASD, 2014). Under extensive fish culture and inadequate administrative and control measures, fish farms are vulnerable to great hazards due to the infection with parasites and other disease agents (Mhaisen,1993a,b; 1996). Many parasite species can easily spread among fishes suffering from crowd and badmanagements, especially those parasites with direct life cycles (Mhaisen et al, 2012). Among notable parasitological investigations achieved on fishes from Euphrates River within the Iraqi territory are those of Mhaisen et al (1997), Al-Alusi (1998), Asmar et al (1999), Al-Awadi (2003), Balasem et al (2003), Al-Zubaidy (2007) and Hussain (2007, 2008). Al-Jawda and Asmar (2014) recorded 16 species of myxosporeans infecting 5 species of fish collected from three sites at Tigris River (Al-Taji, Al Shawaka and Al-Zaafaraniya) of Baghdad province. Myxosporeans included one species; Chloromyxum. Mhaisenet al (2015) reported that ciliophoran and myxozoan parasites of fishes from the Euphrates River at Al-Musaib City, Babylon province, mid Iraq were inspected for parasites. Among the total of 65 parasite species recorded from these fishes, three ciliates (Phylum Ciliophora) and two myxosporeans (Phylum Myxozoa) were recorded. Abdullah and Abdullah (2015) investigated some observations on fishes and their parasites of Darbandikhan Lake, Kurdistan Region, North Iraq. Mhaisen and Al-Rubaie (2016) surveyed the literature concerning the parasites so far recorded from fish farms of Babylon province showed the presence of 92 parasite species. These parasites included onemastigophoran, three apicomplexans, 13 ciliophorans, five myxozoans, five trematodes, 45 monogeneans, five cestodes, three nematodes, two acanthocephalans, nine arthropods, and one mollusc. Binni, Barbuss haarpeyi (Gunther, 1874), is one of the most widely distributed riverine-cyprinid species in southern and mid parts (marshes) of Tigris-Euphrates basin (Banister, 1980). This specie is scarce in Northern of Baghdad on Tigris and Ramadi on Euphrates. Recently there is a semi-isolated population in north bays of Tharthar reservoir. Due to recent reduction of water level of many parts of Tigris and Euphrates and exposition of traditional spawning grounds to dryness (Ali and Tomas, 2009), the natural reproduction becomes insufficient and the need to culture this specie became evident in recent years. Thus, the present author undoubtedly suggested that this species (Binni) can prosperously culture in the common carp ponds, basins or/and even cages. Because the $B$. sharpeyi considered most important among other local cyprinid species for its high economical and consumption values, it has specific eco-biological characteristics that make it a promising for aquaculture. In the present study, caudal my-xosporidiasis and the ultrastructural characteristics of Myxobolus caudatus (Ali et al, 2002) infecting binni fish, Barbuss hapreyi Günther, 1874(F: Cyprinidae) collected from coasts of Euphrates river at Ramadi City, Iraq were described using light and transmission electron microscopy (TEM).

\section{Materials and Methods}

A total of 26 freshly caught binni fish, Barbuss hapreyi Günther, 1874 (F: Cyprinidae) were collected from Euphrates river at Ramadi City, Iraq during regular visits between March and September 2016. Fish samples were transported alive immediately to the laboratory where they were examined for myxosporean infection. Firstly, fish skin and gills were firstly examined by naked eyes for the detection of any macroscopically visible lesions or cysts. Gills were scrapped gently to prevent excess blood in the sample and then examined. Gross microscopic examinations of internal organs for myxosporidian infections were done. To study the morphology of the mature spores and for taxonomic measurements, at least one fresh plasmodium was taken from each infected fish, ruptured to release their spores, spread on glass slides and photographed. Smears of 
parasite cysts were prepared, air dried for 1 $\mathrm{h}$, fixed in absolute methanol and stained with Giemsa stain in phosphate buffer $(\mathrm{pH}$ 7.2) for $1 \mathrm{~h}$. Given measurements of spores were the mean \pm S.D. (range) of 50 samples of fresh and stained spore preparations. Classification, measurements and description of spores were carried out according to guidelines of Lom and Arthur (1989). For morphologic and morphometric study, photomicrographs were taken using photo research Zeiss Axiovert 135 light microscope with Canon digital Camera. Drawings were made by the help of a camera Lucida.

\section{Results}

Myxobolus caudatus (Ali et al, 2002)

Plasmodia (Figs. 1-12): Plasmodia of this parasite were collected from caudal fin of infected host. Plasmodia appeared as small, white, oval spots in between caudal fin and close to the caudal peduncle. The number of plasmodia per infected fish was 3-4 and measured $0.25-0.46(0.37 \pm 0.02) \mathrm{mm}$ in diameter.

Description of spores: Spores were elliptical in shape, measured 11.6-13.7 (12.9 \pm 2$)$ $\mu \mathrm{m}$ in length and 6.4.0-8.3 (7.4 \pm 2$) \mu \mathrm{m}$ in width. The polar capsules were elliptical equal in size, pointed at their anterior. They measured 7.2-8.5 (7.5 \pm 0.5$) \mu \mathrm{m}$ in length and 2.2-4.3 (3.4 \pm 0.5$) \mu \mathrm{m}$ in width.

\section{Taxonomic summary:}

Myxozoa, Myxosporea, Bivalvulida, Myxobolidae

Type species: Myxobolus caudatus (Ali et al, 2002)

Type host: Binni fish, Barbusshapreyi Günther (1874)

Type habitat and infection site: Tail fin of host fish.

Type locality: Euphrates River at Ramadi City, Iraq

Prevalence: Eight/26B. bynni fishes with a percentage of $30.8 \%$ were found to be naturally infected.

TEM examination of the ultrathin sections showed that the process of capsulogenesis and valvogenesis followed the usual pattern of myxozoa development in host fish.

Capsulogenesis: Spores of the present species was characterized by the presence of the capsulogenic cells with relatively large amounts of endoplasmic reticulum, several mitochondria, an elongated nucleus and the formation of polar capsules within their cytoplasm. The capsules appeared as membrane-bounded, bulb-like dense and dark structures known as capsular primordia with surrounding external tubules which are the origin of polar filaments with connections between primordia and the external tube were observed. Within the cytoplasm of each capsulogenic cell, the external tube formed several loops and terminated within the developing polar filament discharge canal. Coils and folds of the developing polar filament were observed, 6-9 in number. In mature spores, polar capsules were elongated, consisted of an electron-lucent zone and a fine granular cortex with a polar filament coiled several times. The development of polar capsules was not always synchronized; one polar capsule may have been completely developed, while the other still had the shape of the primordium or as an immature stage. Sporoplasm cells with small sporoplasmosomes were also observed adjacent to the capsulogenic cells.

Valvogenesis:Two valvogenic cells on each pole usually surrounded the two capsulogenic cells and evidently gave rise to the two valves surrounding each spore, the structural ridge between the valves and the two discharge canals called sutural ridges occurred at the desmosomal junctions of dropping valvogenic cells.

\section{Discussion}

Myxobolus caudatus: Generally, little was known about the myxospordian parasites infecting fishes of the Euphrates River at Ramadi City, Iraq. The only study in this area was of Al-Joudi and Ghazal (2005) who reported the intestinal parasitic infection in Ramadi, Iraq, during the periodextending from 1992 until 1997 carried on human pa- 
tients. Previous records of myxozoan parasites infecting the binni fish from Euphrates river were reported. M. pfeifferi infecting Acanthobrama centisquama, A caeruleus, Aphanius dispar, B. grypus, $C$. luteus, $C$. macrostomum, C. carpio, L. vorax, L. abuand M. sharpeyi (Asmar et al, 1999; AlAwadi, 2003; Balasem et al, 2003; AlZubaidy, 2007). So far, $M$. pfeifferis the prevalent myxozoan among fishes of Iraq as it has 35 fish-host species (Mhaisen et al, 2015). Myxidiumrhodei Léger (1905) from $M$. sharpeyi was reported as B. sharpeyi, from Al-Qadisiya Dam Lake, northwest of Baghdad (Balasem et al, 1997). Myxobolus oviformis Thélohan (1882) from Leuciscus vorax was reported as Aspius vorax, Luciobarbus esocinus was reported as $B$. esocinus, Arabibarbus grypus was reported as Barbus grypus and $M$. sharpeyi was reported as $B$. sharpeyi from different inland waters of Iraq (Herzog, 1969). Since the site of infection as well as morphometry and shape of the recovered spores coincide with a type species recovered previously from host species of the same genus which is $M$. caudatus from the $B$. binni from the River Nile, Egypt, the parasite should be classified as the same. The morphological and morphometric features of our species recorded coincide to those described by Ali et al (2002). The dimensions of spore and polar capsules of Myxobolus caudatus Ali et al. (2002) were larger than those of the present study. $M$. cycloides was similar in shape with the $M$. caudatus of the present study with smaller dimensions and had 5-6 notches in the inner wall of spores and different number of polar filament coils. The present myxosporidian was recorded from the tail fin of Barbus shapreyi as new host and locality records from Euphrates River at Ramadi City, Iraq.

\section{Conclusion}

The parasite recorded in the present study represents new host and locality records and it is recommended to focus the future parasitological studies on parasites infecting fishes in Euphrates River at Ramadi City, Iraq as many of parasitic fauna are still unknown.

\section{References}

Abdel-Ghaffar, F, Abdel-Gaber, R, Maher, S, El Deeb, N, Kamel, R, et al, 2017: Morphological \& ultrastructural characteristics of Myxobolus ridibundaen. sp. (Myxosporea: Bivalvulida) infecting the testicular tissue of marsh frog Ranaridibunda (Amphibia: Ranidae) in Egypt. Parasitol. Res. 116:133-41.

Abdullah, SY, Abdullah, M AS, 2015: Some observations on fishes and their parasites of Darbandikhan Lake, Kurdistan Region in North Iraq. Euro. Sci. J. 409-17.

Al-Awadi, HMH, 2003: Parasitic faunae (Protozoa and Monogenea) of six species of fish from Euphrates River near Kufa district (Najaf Al-Ashraf province), Iraq. Babylon Univ. J. Pure Appl. Sci., 8, 3: 529-32.

Ali, AM, Tomas, NK, 2009: Some ecological aspects of bizz Barbusesocinus heckel, 1843 (Actinopterygii, Cyprinidae) from tigris and Euphrates Rivers, Iraq. Trop. Freshwater Biol. 18, 1:27-50.

Ali, MA, Al-Rasheid, KA, Sakran, T, AbdelBaki, AA, Abdel-Ghaffar, FA, 2002: Some species of the genus Myxobolus (Myxozoa: Myxosporea) infecting freshwater fish of the River Nile, Egypt and the impact on their host. Parasitol. Res. 88:9-15.

Al-Joudi, FS, Ghazal, AM, 2005: the prevalence of intestinal parasites in Ramadi, Iraq. Bull. Pharm. Sci., Assiut University. 28, 2:27781.

Al-Jawda, MJ, Asmar, RK, 2013: Myxosporeans (Phylum Myxozoa) parasitic on some fishes from Tigris River at North, Mid and South of Baghdad Province, Iraq. Basrah J. Agric. Sci. 26, 1:106-16.

Al-Zubaidy, AB, 2007: A study for some protozoan fauna of freshwater fishes from Hilla River, Babylon province, Iraq. Afr. J. Biol. Sci. 2, 2: 97-104.

Asmar, KR, Balasem, AN, Mhaisen, FT, AlKhateeb, GH, Al-Jawda, JM, 1999: Survey of the parasites of some fish species from AlQadisiya Dam Lake, Iraq. Ibn Al-Haitham J. Pure Appl. Sci. 12, 1:52-61.

Balasem, AN, Mhaisen, FT, Al-Khateeb, GH, Asmar, KR, 1997: Recording of two species of MyxidiumBütschli, 1882 (Sporozoa: Myxospor- 
idia) for the first time in fishes of Iraq. Al-Mustansiriya J. Sci. 8, 3:92-5.

Balasem, AN, Mhaisen, FT, Adday, TK, AlJawda, JM, Asmar, KR, 2003: A second survey of parasitic infections in freshwater fishes from Al-Qadisiya Dam Lake, Euphrates River, Iraq. Mar. Mesopot. 18, 2:123-40.

Banister, KE, 1980: The Fishes of the Tigris and Euphrates Rivers. In: Euphrates and Tigris, Mesopotamian Ecology and Destiny, Rzoska, J. (Ed.). W. Junk, Netherlands.

Herzog, PH, 1969: Unter-suchungenüber die parasiten der süßwasserfische des Irak. Arch. Fischereiwiss. 20, 2/3:132-47.

Hussain, HT, 2007: Survey of ectoparasites of some fishes of Al-Hilla River in Babylon province. J. Babylon Univ. Sci. 14, 3:228-32.

Hussain, HT, 2008: Study on the external ectoparasites of mosquito fish (Gambusiaaffinis) in Al-Hilla River, Babylon province. J. Babylon Univ., Pure Appl. Sci. 15, 1:245-8.

Cech, G, Molnár, K, Székely, C, 2012: Molecular genetic studies on morphologically indistinguishable Myxobolus spp. infecting cyprinid fishes, with the description of three new species, $M$. alvarezae sp. nov., $M$. sitjae sp. nov. and $M$. eirasianus sp. nov. Acta Parasitol. 57: 354-66.

Eiras, JC, Molnár, K, Lu, YS, 2005: Synopsis of the species of Myxobolus Bütschli, 1882 (Myxozoa: Myxosporea: Myxobolidae). Syst. Parasitol. 61:1-46.

Eiras, JC, Zhang, J, Molnár, K, Lu, YS, 2014: Synopsis of the species of Myxobol us Bütschli, 1882 (Myxozoa: Myxosporea: Myxobolidae) described between 2005 and 2013 . Syst. Parasitol. 88:11-36.

Eszterbauer, E, 2004: Genetic relationship among gill-infecting Myxobolus species (Myxosporea) of cyprinids: molecular evidence of importance of tissue-specificity. Dis. Aquat. Org. 58:35-40.

Fiala, I, Bartošová-Sojková, P, Whipps, CM, 2015: Classification and phylogenetics of Myxozoa. In: Okamura B, Gruhl A, Bartholomew JL (eds) Myxozoan evolution, ecology and development: Springer International Publishing, Switzerland.

Landsberg, JH, Lom, J, 1991: Taxonomy of the genera of the Myxobolus/Myxosoma group
(Myxobolidae: Myxosporea), current listing of species and revision of synonyms. Syst. Parasitol. 18:165-86.

Lom, J, Dyková, I, 2006:Myxozoan genera: definition and notes on taxonomy, life-cycle terminology and pathogenic species. Folia Parasitol. 53:1-36.

MASD, 2014: Ministry of Agriculture, Statistical Data on Fish Farms in Different Provinces of Iraq up to 31 December 2014, Ministry of Agriculture, Baghdad, Iraq.

Mhaisen, FT, 1993a: A review on the parasites and diseases in fishes of ponds and farms of Iraq. Iraqi J. Vet. Sci. 6, 2:20-28,.

Mhaisen, FT, 1993b: The role of wild fishes in fish farms of Iraq from parasitological and pathological points of view Iraqi J. Vet. Sci. 17: 126-36.

Mhaisen, FT, 1996: Natural enemies of farm fishes with special emphasis on fish farms of Iraq. Al-Tharwa Al-Samakia (Fisheries).14:92-8. Mhaisen, FT, Al-Niaeem, KS, Al-Zubaidy, AB, 2012: Literature review on fish parasites of al-furat fish farm, Babylon Province, Iraq. Iraqi J. Aqua. 9, 1:95-122.

Mhaisen, FT, Al-Rubaie, AL, Al-Saadi, BA, 2015: Ciliophoran and myxozoan parasites of fishes from the Euphrates River at Al-Musaib City, Babylon Province, Mid Iraq. American J. Biol. Life Sci. 3, 1:12-6.

Mhaisen, FT, Al-Rubaie, AL, 2016: Checklists of Parasites of Farm Fishes of Babylon Province, Iraq. J. Parasitol. Res. 8:1-15.

Molnár, K, 1994: Comments on the host, organ and tissue specificity of fish myxoporeans and on the types of their intrapiscine development. Parasitol. Hung. 27:5-20.

Molnár, K, 2002a: Site preference of fish myxosporeans in the gill. Dis. Aquat. Org. 48: 197-207.

Molnár, K, 2002b: Site preference of myxosporean spp. on the fins of some Hungarian fish species. Dis. Aquat. Org. 52:123-8.

Molnár, K, Eszterbauer, E, 2015: Specificity of infection sites in vertebrate hosts. In: Okamura B, Gruhl A, Bartholomew JL (eds) Myxozoan evolution, ecology and development. Springer International Publishing, Switzerland. 
Table 1: Comparison between morphometrical data (in $\mu \mathrm{m}$ ) of present $M$. caudatus with others previously.

\begin{tabular}{|l|l|l|l|l|}
\hline \multirow{2}{*}{ Type species } & \multicolumn{2}{|c|}{ Spore } & \multicolumn{2}{c|}{ Polar capsule } \\
\cline { 2 - 5 } & \multicolumn{1}{|c|}{ length } & width & length & width \\
\hline $\begin{array}{l}\text { Myxoboluscaudatus } \\
\text { (Ali et al, 2002) }\end{array}$ & $16.0-19.2(17.5 \pm 1.3)$ & $11.0-13.6(12.8 \pm 0.9)$ & $6.4-9.0(7.4 \pm 0.7)$ & $3.2-4.5(3.8 \pm 0.5)$ \\
\hline $\begin{array}{l}\text { Myxoboluscaudatus } \\
\text { (Present study) }\end{array}$ & $11.6-13.7(12.9 \pm 2)$ & $6.4 .0-8.3(7.4 \pm 2)$ & $7.2-8.5(7.5 \pm 0.5)$ & $2.2-4.3(3.4 \pm 0.5)$ \\
\hline
\end{tabular}

\section{Explanation of Figures}

Figs. 1-4: Photomicrographs showing: 1,2fresh spores (S) of $M$. caudatus liberated from their plasmodia, two polar capsules $(\mathrm{PC})$ and posterior vacuoles (PV) were observed (Fig. $1 \times 900$; Fig. $2 \times 1200$ ); 3, 4: Giemsa stained spore (S) with darkly stained polar capsules $($ PC) $($ Fig. $3 \times 700$; Fig. $4 \times 1200)$.

Figs.5-8: TEM showing the process of capsulogenesis:5, 6: immature spores within an enveloping cell (EC), two capsulogenic cells (CC) were observed, one of them with capsular primoridia (CP) which is the first recognizable stage. External tubule (ET) appears adjacent to the primordium; the other capsulogenic cell with a mature polar capsule (PC) with polar filament coils (PF) (asynchronous development), observe the attachment between the primordium and external tubule in fig. 8, $\mathrm{N}$ for nucleus.7,8: mature spores with capsulogenic cells (CC) and polar capsules (PC) with fully formed filament coils (PF). Terminally at two ends of spore, there are valvogenic cells (VC) each two meet together at a suture line. A sporoplasm cells (SC), beside capsulogenic cells with sporoplasmosomes (SS).(Figs.5,6,8 ×12000; Fig. $7 \times 17500$ ).

Figs. 9-12: TEM showing: 9, 10: high magnification of a mature polar capsules (PC) containing fully formed filament coils (PF). 11, 12: the process of valvogenesis. Valvogenic cells (VC) arranged at the edges of spores; where each two cells meet at valvogenic suture (VS).(Figs. 9, $12 \times 22000$; Fig. $10 \times 27000$; Fig. $11 \times 23000$ ).

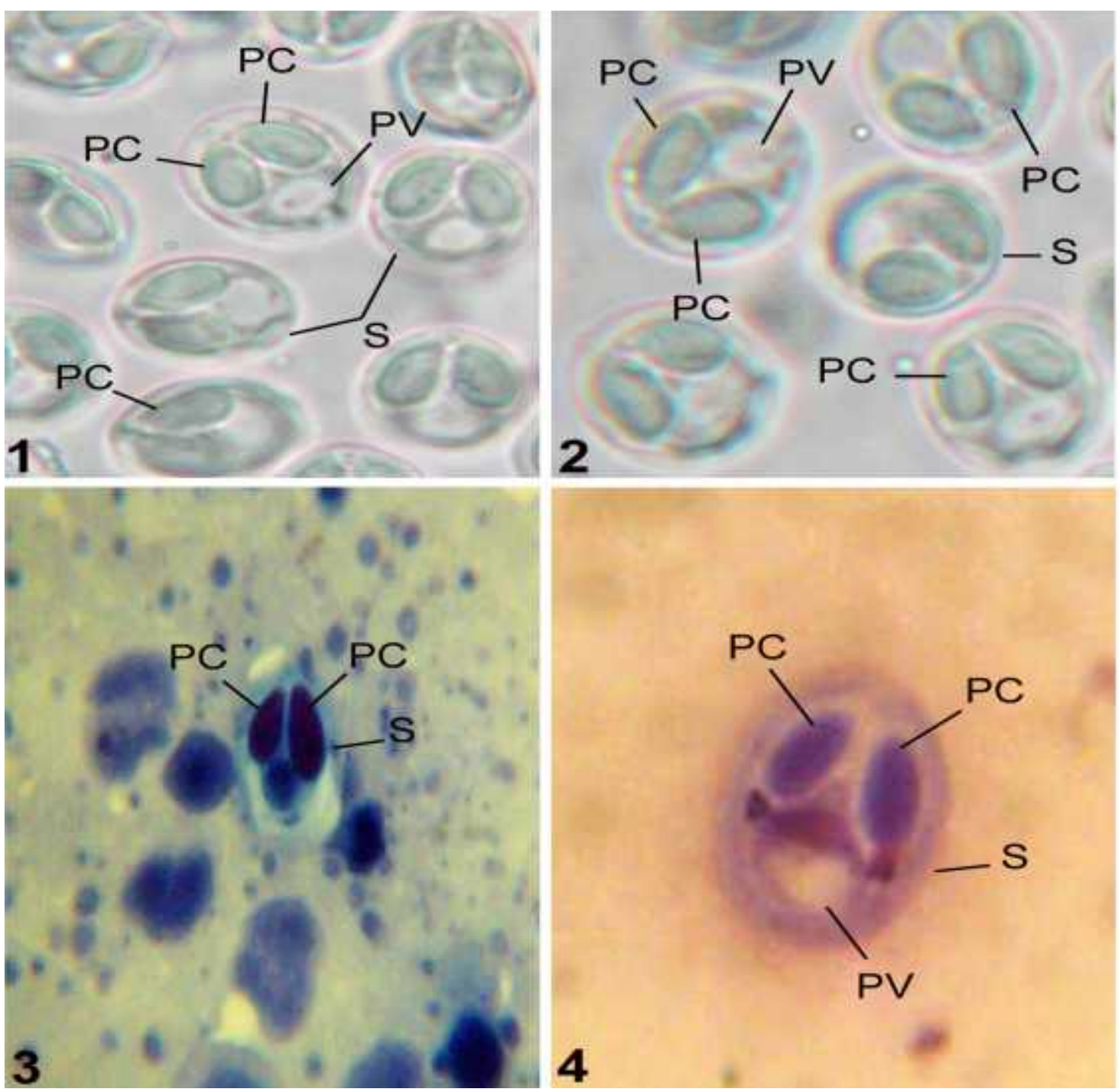




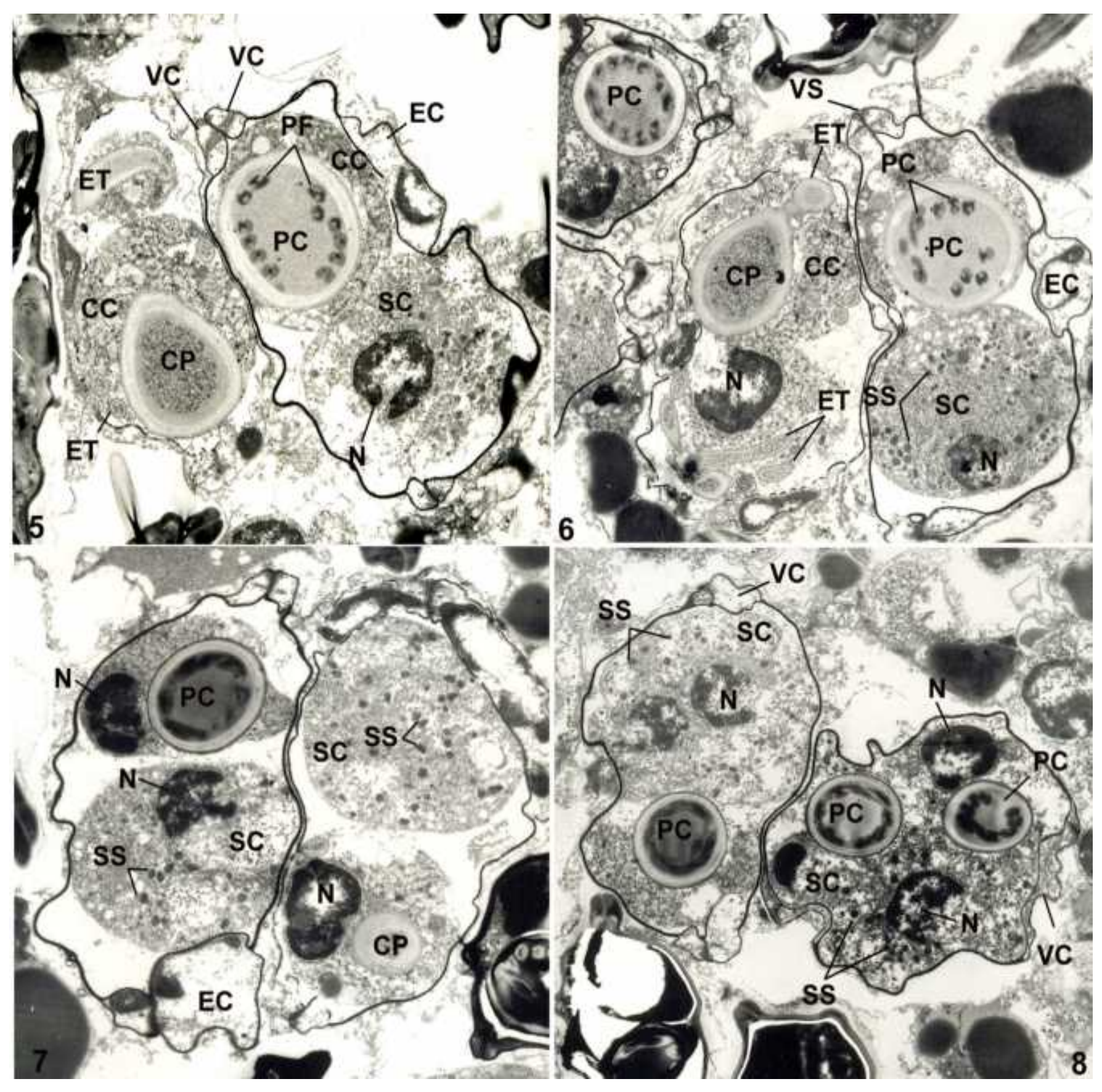




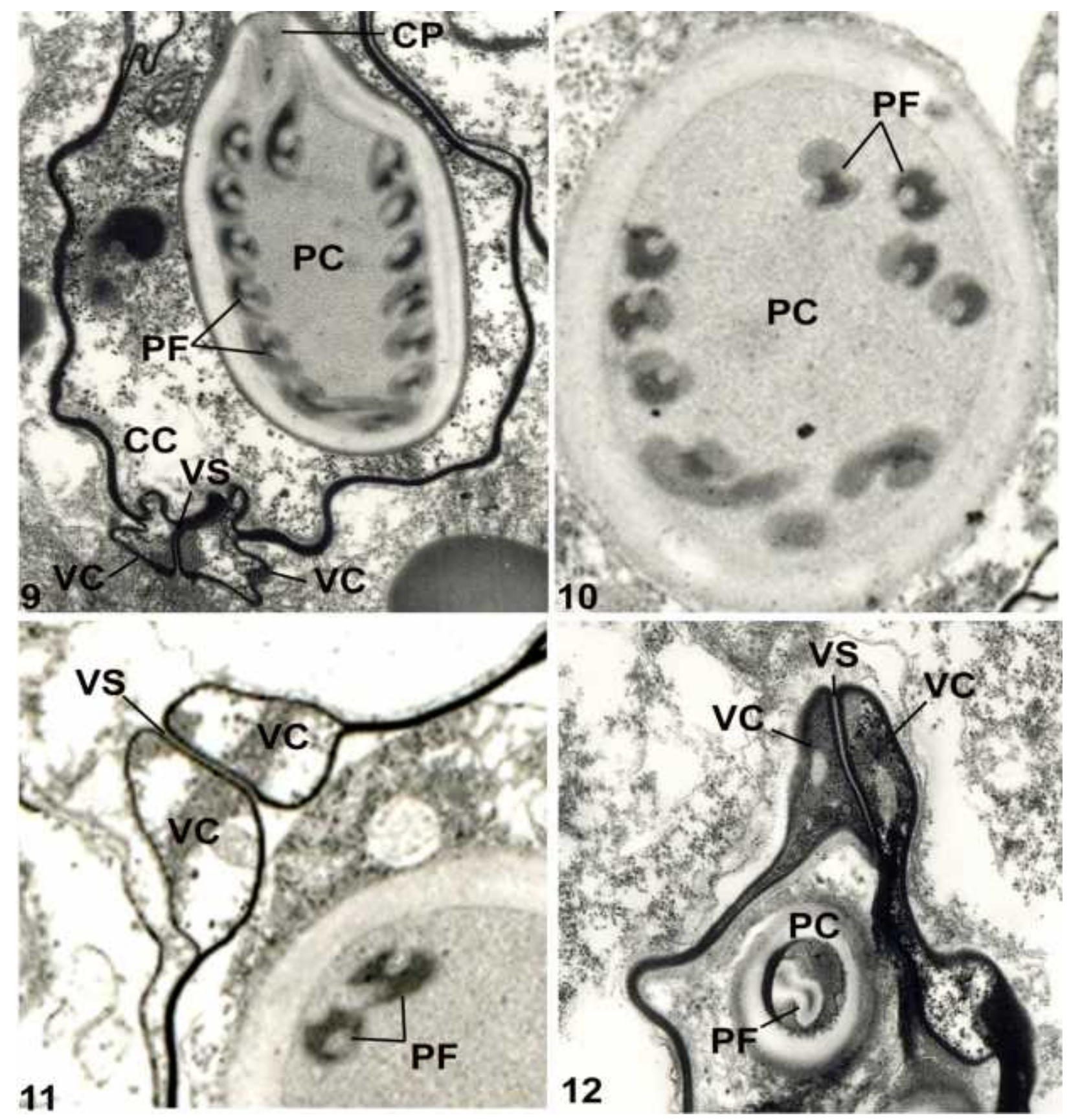

